\title{
Recent approaches in food bio-preservation - a review
}

\author{
Veer Pal Singh* \\ Department of Livestock Products Technology, College of Veterinary Science and Animal Husbandry, U.P. Pt. Deen \\ Dayal Upadhyay Veterinary University and Go Anusandhan Sansthan, Mathura, U.P. 281001 India
}

\begin{abstract}
Bio-preservation is a technique of extending the shelf life of food by using natural or controlled microbiota or antimicrobials. The fermentation products as well as beneficial bacteria are generally selected in this process to control spoilage and render pathogen inactive. The special interest organism or central organism used for this purpose is lactic acid bacteria (LAB) and their metabolites. They are capable to exhibit antimicrobial properties and helpful in imparting unique flavour and texture to the food products. The major compounds produced by LAB are bacteriocin, organic acids and hydrogen peroxide. Bacteriocin is peptides or proteins with antimicrobial activity. On the basis of size, structure and post-translational modification, bacteriocin is divided into four different classes. Due to non-toxic, nonimmunogenic, thermo-resistance characteristics and broad bactericidal activity, LAB bacteriocins are considered good bio-preservative agents. The most common LAB bactriocin is nisin which has wider applications in food industry and has been Food and Drug Administration (FDA) approved. Nisin and other bacteriocin are being used in vegetables products, dairy and meat industries. Apart from LAB metabolites, bacteriophages and endolysins has promising role in food processing, preservation and safety. Bacteriocins and endolysins are more suitable for DNA shuffling and protein engineering to generate highly potent variants with expanded activity spectrum. Genetically modified bacteriophages may also be helpful in bio-preservation, however; their safety issues must be addressed properly before selection as bio-preservative agent.

Keywords: Bacteriocins, Bacteriophages, Bio-preservation, Endolysins, Lactic acid bacteria.
\end{abstract}

\section{Introduction}

The foods of animal origin are highly perishable due to high nutritional content, moisture and neutral $\mathrm{pH}$. These foods require proper preservation to maintain quality and safety. Failing which leads to human illnesses and disease outbreaks. These food borne illnesses are serious and costly public health concern worldwide. So to maintain the quality and safety of foods various measures are generally adopted in food industry i.e. good manufacturing practices, good hygienic practices tec. But preservation of food by a suitable means is the key of food quality and safety. There are number of preservation techniques started from low temperature preservation like refrigeration, freezing etc. and thermal preservation techniques like pasteurization, sterilization and preservation using certain chemicals. Now a day modern preservation techniques like bio-preservation, irradiation and hurdle technologies are also common. In traditional preservation techniques food alters their status and loss some nutrients. So the modern techniques are more suitable to achieve the safety and quality of foods. It is also relevant in today world due to globalization of food market, introduction of novel foods, innovations of new technologies, demand of minimally processed products with ready-to-eat quality and longer shelf life. Among all the preservation techniques adopted now biopreservation is more reliable from 'farm to fork' concept. It is capable to enhance shelf life with great quality, hygienic status with minimal nutritional and organoleptic losses.

Bio-preservation is a technique of food preservation in which antimicrobial potential of naturally occurring organisms and their metabolites are exploited. It is capable to harmonize and rationale the necessary safety standards with traditional means of preservation and modern demand of the food safety and quality. The biopreservation techniques of various foods are mainly relying on the quality of biological antimicrobial systems such as lactic acid bacteria (LAB) and/or their bacteriocins, bacteriophages and bacteriophageencoded enzymes. They are widely used in food industry to get a typical texture and flavour of the food products. They are helpful in maintaining the quality and safety of foods and are common bio-preservatives in industrialized world.

\section{Biological methods for food preservation}

The use of microbiota and/or antimicrobials in shelf life enhancement of foods is a new branch of science. The fermentation is a typical example of this process in which microbes are grown naturally or by addition. Fermentation process produces numbers of beneficial 
products with the bacteria which helps in reduction of food spoilage and renders the food free from pathogenic microorganisms and metabolites (Ganguly, 2013). This process is gradually gaining popularity due to its ecologically benign approach. The main organism used for the purpose is LAB and their compounds like organic acids which are capable to exert antimicrobial properties as well as imparts unique flavour and texture to the food products (Lucera et al., 2012). Number of food products is preserved by fermentation since time immoral. In industrialized world about 60 percent food items are subjected to fermentation to assure homogeneity, quality, and safety of products. They prefer to use native microbiota under controlled environment to get typical texture and flavour for a specific product. The major use of microbiota in food industry is in dairy industry but they can also be exploited in meat and vegetable products. Biopreservatives eligible for use in food must fall under the category of generally recognized as safe with no pathogenic and toxic effect on food. Biological agents used in food may be categorized as starter cultures and protective cultures. Starter cultures are generally used group of microorganisms which are used to initiate the fermentation and helps in production of certain compounds responsible for typical texture and flavouring compounds in fermented products. The protective culture is mainly used to control the antimicrobial activity and reduces the survival and growth of pathogenic micro-organisms in foods. However, combination of both starter and protective culture is generally preferred for use in food industry.

\section{Natural antimicrobials for food bio-preservation}

Natural antimicrobials for food bio-preservation are shown in Table 1.

\section{Lactic acid bacteria (LAB)}

LAB is generally includes Lactococcus, Streptococcus, Lactobacillus, Pediococcus, Leuconostoc, Enterococcus, Carnobacterium, Aerococcus, Oenococcus, Tetragenococcus, Vagococcus, and Weisella genera of microorganismsm. All these micro-organisms are Grampositive, nonmotile, non-sporeforming, rod- and coccus-shaped organisms and are capable to ferment carbohydrates. The chief product obtained after fermentation is lactic acid. Composition wise LAB contains low proportions of $\mathrm{G}+\mathrm{C}$ in their DNA $(<55 \%)$ which provides more thermostability to the organism. Physiologically LAB possess unique properties like resistance to bacteriophages, proteolytic activity, lactose and citrate fermentation, production of polysaccharides, high resistance to freezing and lyophilization, capacity for adhesion and colonization of the digestive mucosa, and production of antimicrobial substances.
The basic function of LAB is in food fermentation and recognized as GRAS (generally recognized as safe). LAB can be utilized in production of various fermented products of dairy, meat and vegetable. It helps in protection of nutritional qualities of raw material, enhances the shelf life of food and protects food against spoilage and pathogenic organisms.

Major compounds produced in LAB fermentation are organic acids, hydrogen peroxide and bacteriocins. Additionally LAB can be utilized in production of probiotics.

The genera Lactobacillus and Bifidobacterium are of major concern in this field and are mainly obtained from human gastrointestinal tracts. Other probiotic organisms may be summarized as E. faecium, E. faecalis, S. thermophilus, L. lactis subsp. lactis, Le. mesenteroides, and P. acidilactici.

\section{Bacteriocins}

Bacteriocins are bacterial ribosomally synthesized peptides or proteins with antimicrobial activity. Initially bacteriocins are mainly described to the colicins which are relatively large proteins of up to 80 $\mathrm{kDa}$ and were primarily obtained from E. coli. They were capable to kill very closely related bacteria upon binding to the inner membrane or other cytosolic targets (García-Bayona et al., 2017).

However, today world is recognizing the bacteriocins as small, heat-stable cationic peptides synthesised by Gram positive bacteria called LAB and possess wider spectrum of inhibition (Mokoena, 2017). Traditionally LAB is regarded as safe for use in food so the food biopreservation is mainly rely on the use of LAB bacteriocins. The classification of bacteriocins in major classes with their quality characteristics are listed in Table 2.

\section{LAB bacteriocins}

Bacteriocins produced by LAB which are capable to kill closely related micro-organisms. Bacteriocins produced by LAB are thermostable cationic molecules contains up to 60 amino acid residues and hydrophobic patches. The effectivity of LAB bacteriocin is mainly due to electrostatic interactions with negatively charged phosphate groups on target cell membranes through initial binding, forming pores and killing the cells leads to lethal damage and autolysin activation to digest the cellular wall. But by nature these bacteriocins are inactivated by proteases in the gastrointestinal tract. However, LAB bacteriocins are considered good biopreservative agents due to non-toxic, nonimmunogenic, thermo-resistance characteristics and broad bactericidal activity. These bacteriocins are most effective against Gram-positive bacteria and some, damaged, Gram-negative bacteria including various pathogens such as L. monocytogenes, Bacillus cereus, S. aureus, Salmonella etc. 
Table 1. Natural antimicrobials for food bio-preservation.

\begin{tabular}{|c|c|c|c|}
\hline & Antimicrobials & Source & Food bio-preservation \\
\hline \multirow{6}{*}{ 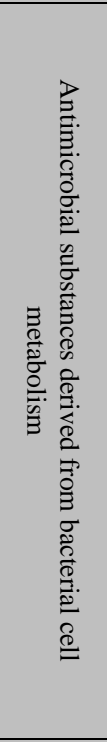 } & Organic acids & Main end products of fermentation. & $\begin{array}{l}\text { Decrease the pH of surrounding environment, } \\
\text { creating a selective barrier against non- } \\
\text { acidophiles. } \\
\text { Lactic acid exerts antimicrobial effect by } \\
\text { disruption of the cytoplasmic membrane and } \\
\text { interference with membrane potential. }\end{array}$ \\
\hline & $\mathrm{CO}_{2}$ & $\begin{array}{l}\text { Heterofermentative } \mathrm{LAB} \text { produces } \mathrm{CO}_{2} \text { as } \\
\text { a byproduct of sugar fermentation. }\end{array}$ & $\begin{array}{l}\text { Creation of an anaerobic environment and } \\
\text { antagonistic effects specifically against aerobic } \\
\text { bacteria and produce carbonic acid. }\end{array}$ \\
\hline & Diacetyl (2,3-butanedione) & LAB as a by-product of metabolic activity & $\begin{array}{l}\text { Antibacterial activity against Listeria, Salmonella, } \\
\text { Escherichia coli, Yersinia, and Aeromonas. }\end{array}$ \\
\hline & Hydrogen peroxide & $\begin{array}{l}\text { Produces by LAB in presence of oxygen } \\
\text { and action of flavoprotein oxidases or } \\
\text { NADH peroxidase. }\end{array}$ & $\begin{array}{l}\text { Antibacterial effect through oxidative damage of } \\
\text { proteins and increase of membrane permeability. }\end{array}$ \\
\hline & Reuterin & $\begin{array}{l}\text { Low molecular- weight antimicrobial } \\
\text { compound produced by Lactobacillus } \\
\text { reuteri and some other LAB. }\end{array}$ & $\begin{array}{l}\text { Antimicrobial activity against bacteria as well as } \\
\text { yeasts and molds by inhibiting DNA synthesis. }\end{array}$ \\
\hline & Reutericyclin & Reutericyclin-producing strains of LAB. & $\begin{array}{l}\text { Reutericyclin acts as a proton ionophore and } \\
\text { dissipation of the proton motive force against } \\
\text { gram-positive bacteria including Lactobacillus } \\
\text { spp., Bacillus subtilis, Bacillus cereus, } \\
\text { Enterococcus faecalis, Staphylococcus aureus and } \\
\text { Listeria innocua. }\end{array}$ \\
\hline 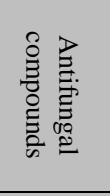 & Natamycin (pimaricin) & Produced from Streptomyces natalensis & $\begin{array}{l}\text { Broad-spectrum antifungal biopreservative for } \\
\text { foods and beverages by binding irreversibly to the } \\
\text { cell membrane of fungi and causes membrane } \\
\text { hyperpermeability leading to rapid leakage of } \\
\text { essential ions and peptides and ultimately cell } \\
\text { lysis. }\end{array}$ \\
\hline \multirow{7}{*}{ 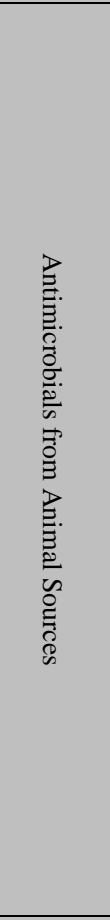 } & Lysozyme & $\begin{array}{l}\text { Naturally found as part of defense system } \\
\text { of living organisms. }\end{array}$ & $\begin{array}{l}\text { Generally recognized as safe (GRAS) for direct } \\
\text { addition to foods. }\end{array}$ \\
\hline & Lactoferrin & $\begin{array}{l}\text { Natural protein found in milk and other } \\
\text { secretions. }\end{array}$ & $\begin{array}{l}\text { Antimicrobial activity due to its iron-binding } \\
\text { capacity and polycationic nature against a wide } \\
\text { range of bacteria including foodborne pathogens } \\
\text { like Carnobacterium, Listeria monocytogenes, } \\
\text { Escherichia coli, Klebsiella and viruses } \\
\text { (Lönnerdal, 2011; Gyawali and Ibrahim, 2014). }\end{array}$ \\
\hline & Lactoperoxidase & $\begin{array}{l}\text { Antimicrobial system that originated from } \\
\text { milk. }\end{array}$ & Effective against gram-negative bacteria. \\
\hline & Ovotransferrin & Produced by hydrolysis of natural proteins. & Inhibits bacterial growth due to iron deprivation. \\
\hline & Protamine & $\begin{array}{l}\text { Naturally present in spermatic cells of fish, } \\
\text { birds and mammals. }\end{array}$ & $\begin{array}{l}\text { Broad antimicrobial activity against gram-positive } \\
\text { bacteria, gram-negative bacteria, and fungi. } \\
\text { Used as preservative in wide variety of foods } \\
\text { ranging from confection items to fruits and rice. }\end{array}$ \\
\hline & Pleurocidin & $\begin{array}{l}\text { Present in myeloid cells and mucosal } \\
\text { tissues of many vertebrates and } \\
\text { Invertebrates. }\end{array}$ & $\begin{array}{l}\text { Antimicrobial activity against several foodborne } \\
\text { bacteria such as } L . \text { monocytogenes and } E \text {. coli } \\
\mathrm{O} 157: \mathrm{H} 7 \text {, and pathogenic fungi. }\end{array}$ \\
\hline & Chitosan & $\begin{array}{l}\text { Polycationic biopolymer naturally present } \\
\text { in exoskeletons of crustaceans and } \\
\text { arthropods. }\end{array}$ & $\begin{array}{l}\text { Considered as safe food additive and has } \\
\text { antibacterial activity against both Gram-positive } \\
\text { and Gram-negative bacteria such as } \\
\text { Staphylococcus aureus, Listeria monocytogenes, } \\
\text { Bacillus cereus, E. coli, Shigella dysenteria, and } \\
\text { Salmonella typhimurium (Gyawali and Ibrahim, } \\
2014 \text { ). } \\
\text { Used in biodegradable edible coatings, singly or } \\
\text { dosed with other antimicrobial substances (Elsabee } \\
\text { et al., 2013). }\end{array}$ \\
\hline 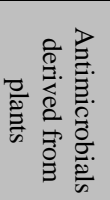 & $\begin{array}{l}\text { Essential oils such as } \\
\text { saponins, flavonoids, } \\
\text { carvacrol, thymol, citral, } \\
\text { eugenol, linalool, terpenes, } \\
\text { and their precursors }\end{array}$ & $\begin{array}{l}\text { Plant material like flowers, buds, seeds, } \\
\text { leaves, twigs, bark, herbs, wood, fruits and } \\
\text { roots. }\end{array}$ & $\begin{array}{l}\text { The concentration of } 0.05-0.1 \% \text { of essential oils } \\
\text { has demonstrated activity against pathogens, such } \\
\text { as Salmonella typhimurium, E. coli } \mathrm{O} 157: \mathrm{H} 7, L \text {. } \\
\text { monocytogenes, B. cereus and } S \text {. aureus in food } \\
\text { systems. }\end{array}$ \\
\hline
\end{tabular}


Table 2. Classification of bacteriocins

\begin{tabular}{|c|c|c|c|c|}
\hline Class & Nomenclature & Qualities & Examples & Reference \\
\hline Class-I & $\begin{array}{l}\text { Post-translationally } \\
\text { modified peptides called } \\
\text { Lantibiotics }\end{array}$ & $\begin{array}{l}\text { Characterized by distinctive } \\
\text { thioether-based intramolecular } \\
\text { rings of lanthionine and } \beta \text { - } \\
\text { methyl-lanthionine }\end{array}$ & $\begin{array}{l}\text { Nisin, discovered } \\
\text { in } 1928, \text { lacticin } L . \\
\text { lactis, citolysin of } \\
\text { E. faecalis, and } \\
\text { lacticin of } L \text {. lactis }\end{array}$ & $\begin{array}{l}\text { Xie and van der } \\
\text { Donk, } 2004\end{array}$ \\
\hline Class-II & $\begin{array}{l}\text { Thermostable, non- } \\
\text { modified non-lantibiotic } \\
\text { linear peptides of < } 10 \\
\mathrm{kDa} \text {. It is recognized as } \\
\text { largest class among Gram } \\
\text { positive bacteriocins and } \\
\text { further divided into three } \\
\text { subclasses based on } \\
\text { distinctive N-terminal } \\
\text { sequence. } \\
\text { i. Class II-1-Pediocin-like } \\
\text { bacteriocins } \\
\text { ii. Class II-2 lacks leader } \\
\text { peptide } \\
\text { iii. Class II-3 other than } \\
\text { above. }\end{array}$ & $\begin{array}{l}\text { Characterized By short cationic } \\
\text { peptides with high isoelectric } \\
\text { points. It contains potent- } \\
\text { antilisteria activity }\end{array}$ & $\begin{array}{l}\text { Pediocin PA- } \\
1 / \text { AcH produced } \\
\text { by Pediococcus, } \\
\text { Enterocin EJ97 by } \\
\text { E. faecalis and } \\
\text { Enterocin L50A } \\
\text { by E. faecalis. }\end{array}$ & Breukink et. al., 1999 \\
\hline Class-III & $\begin{array}{l}\text { Comprises large (> } 30 \\
\text { KDa) heat labile proteins } \\
\text { like colicin- V and } \\
\text { microcins. }\end{array}$ & $\begin{array}{l}\text { Bacteriocins are Gram negative } \\
\text { circular peptides characterized } \\
\text { by a peptide bond between the } \\
\text { C- and N-terminus. It possesses } \\
\text { the bacteriolytic extracellular } \\
\text { enzymes like hemolysins and } \\
\text { muramidases which can mimic } \\
\text { the physiological activities of } \\
\text { bacteriocins. }\end{array}$ & $\begin{array}{l}\text { Helveticin } \mathrm{J} \text { of } L \text {. } \\
\text { helveticus and } \\
\text { bacteriocin Bc- } 48 \\
\text { of } E \text {. faecalis. }\end{array}$ & $\begin{array}{l}\text { Wiedemann et al., } \\
2001\end{array}$ \\
\hline Class-IV & $\begin{array}{l}\text { Circular peptides posses } \\
\text { intriguing and novel type } \\
\text { of antimicrobial } \\
\text { substances produced not } \\
\text { only by bacteria but also } \\
\text { by plants and mammalian } \\
\text { cells. }\end{array}$ & $\begin{array}{l}\text { Characterized by a peptide bond } \\
\text { between the C- and N-terminus } \\
\text { are clustered. They are existed } \\
\text { in form of head-to-tail peptide } \\
\text { chain ligation, which makes } \\
\text { thermmolecules with neither an } \\
\text { origin nor an end. }\end{array}$ & Enterocin AS-48 & Martínez et al., 2008 \\
\hline
\end{tabular}

The genetic manipulation in these bacteriocins is easy to perform due to presence of genetic determinants in plasmid thus variety of natural peptide analogues with desirable characteristics can be produced in shorter period of time. The most common LAB bactriocin is nisin which has wider applications in food industry. Food and Drug Administration (FDA) has approved the use of nisin like bacteriocins produced from GRAS microorganism like Lactococcus lactis into various types of processed cheese, dairy products and canned foods. It is proven fact that Nisin is quite effective against Gram-positive spoilage microorganisms and food-borne pathogens such as L. monocytogenes.

\section{Use of bacteriocins in food systems}

The bacteriocins in general have broad spectrum activity against number of micro-organisms. The application of bacteriocins, particularly nisin, in food systems is influenced by inadequate physical conditions and chemical composition of food including
$\mathrm{pH}$, temperature, nutrients, etc. It is also affected by spontaneous loss in production capacity, inactivation by phage of producing strain and antagonism effect of other microorganisms in foods. The negative factors in its effectivity include resistance against certain pathogens, biological activity interference by certain environmental conditions, higher retention of bacteriocin molecules like fat by food system components, inactivation by other additives, slower diffusion and solubility and/or irregular distribution of bacteriocin molecules in the meat matrix. The prerequisites for use of bacteriocins in food are its production from GRAS micro-organisms, high specific activity of bacteriocins, thermostability, capability to enhance quality and flavour. Bacteriocins must be safe to human health and bio-preservation must fulfill the GRAS regulations. The common bacteriocin named nisin was first time used in 50's to inhibit the outgrowth of Clostridium tyrobutyricum responsible for late 
cheese blowing. However, the major role of bacteriocin is in inhibition of pathogenic and spoilage bacteria during food processing. Nisin has an immediate $\mathrm{pH}$ dependent bactericidal effect and it is further increases with decrease in $\mathrm{pH}$ values (Salem, 2012). The bactericidal effect is obtained by the effect of Lactobacillus acidophilus growth. Thus it can be interpreted that nisin and L. acidophilus is more effective together as compared to the single use.

The commonly used bacteriocins in foods like dairy, meat and vegetable products are lantibiotics nisin and lacticin, pediocin-like bacteriocins and, enterocin AS48 etc. in foods bacteriocins can be applied in three forms i.e. in situ production by starter or protective cultures, as an ingredient of fermentation of a bacteriocinogenic strain and as an additive in a semi- or purified preparation. Among all In situ production is considered cost-effective. Nisin-producing dairy starters are generally designed to specifically inhibit Staphylococcus aureus in acid-coagulated cheeses and C. tyrobutyricum in semi-hard cheeses (Rilla et al., 2003, 2004). Whereas, protective cultures is mainly used to enhance the hygienic quality of raw meat and fish products and do not contribute to sensory attributes of food (Devlieghere et al., 2004). The use of bacteriocins as ingredients or additives requires lowcost food-grade media such as lacticin 3147 and the enterocin AS-48 can best produced in media containing whey (Ananou et al., 2008). It is because whey as a substrate is an attractive option of recycles a by-side product of the dairy industry. Besides bio-preservation bacteriocins have been shown to accelerate cheese ripening by promoting the release of intracellular enzymes to the cheese matrix. Some volatile compounds are responsible for sensory attributes of the matured cheese. Bacteriocins also ensures homogenous fermented products (Ryan et al., 2001) and bacteriocins based food grade markers (immunity proteins) offer the possibility to replace antibiotic selective markers for genetic engineering of food-related bacteria (Brede et al., 2007). The list of commonly occurring bacteriocins and their possible uses are enumerated in Table 3.

A new bacteriocin named sonorensin belongs to heterocycloanthracin subfamily of bacteriocins is found effective against both active and non-multiplying cells of gram +ve as well as gram -ve bacteria. It is showing marked inhibition against biofilm of Staphylococcus aureus. The growth inhibition property of sonorensin is due to increased membrane permeability. Low Density Polyethylene (LDPE) film coated with sonorensin is proved to be effectively control growth of spoilage bacteria like Listeria monocytogenes and Staphylococcus aureus (Chopra et al., 2015). It may be suggested as good alternative to current antibiotics and biopreservative mean for chicken meat and tomato samples.

\section{Bacteriophages}

Bacteriophages or phages are most abundantly found microorganisms on earth and wide spreaded on foods of various origins (Brüssow and Kutter, 2005). They are viruses that specifically infect and multiply in bacteria and are usually harmless to humans, animals, and plants. Most of the bacteriophages are belong to the Caudovirales order and conatins icosahedral head and a double-stranded 179 DNA tail.

Based on tail structures bacteriophages can be classified under three families: Myoviridae with contractile tail, Siphoviridae contains long non contractile tail and Podoviridae family having extremely short tail. Although some of the other bacteriophages are cubic, filamentous or pleomorphic phages with dsDNA, single-stranded DNA, doublestranded RNA or single-stranded RNA (Ackermann, 2007). They may further be classified as virulent and temperate depending on their life cycle. Virulent are generally following the lytic life cycle while temperate enters in lysogenic cycle by inserting their DNA into the bacterial chromosome (prophage). Virulent bacteriophages are capable to lyse the host bacterium and exerted antimicrobial activity (Sulakvelidze and Kutter, 2005; Hanlon, 2007).

\section{Utilization of bacteriophages in food system}

Bacteriophages can suitably be utilized in prevention or inhibition of colonization, control of diseases in livestock through phage therapy, decontamination of carcasses and other raw products such as fresh fruit and vegetables, and to disinfect equipment and contact surfaces by phage bio-sanitation and enhance the shelf life of manufactured foods by phage bio-control. Bacteriophages can be successfully utilized for reduction of pathogen carriage in livestock farming and after slaughter or milking. Bacteriophages are effective against Salmonella (Fiorentin et al., 2005) and Campylobacter (Atterbury et al., 2005) in chicken and pathogenic E. coli (Raya et al., 2006) in ruminants. To achieve biosanitation reduction in biofilm can be obtained (Azeredo and Sutherland, 2008) by reducing or eradication of $S$. aureus nasal or skin colonisation in food handlers (Mann, 2008).

In bio-preservation, bacteriophages can work symbiotically with fermentation organisms during fermentation. It is quite effective method in preparation of food processing's and reduces effectively the like Salmonella in cheddar production (Modi et al., 2001), $S$. aureus growth in curd manufacturing (García et al., 2007; 2009) and complete eradication of Listeria monocytogenes during ripening, and storage of acid coagulated and semi-hard cheeses (Carlton et al., 2005) and inhibition of Enterobacter sakazakii in reconstituted infant formula milk (Kim et al., 2007) and Salmonella typhimurium on chicken frankfurters (Whichard et al., 2003). 
Table 3. Common bacteriocins and their possible uses in food industry.

\begin{tabular}{|c|c|c|}
\hline & Bacteriocin & Food application \\
\hline \multirow{2}{*}{ 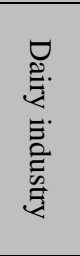 } & Nisin & $\begin{array}{l}\text { Clostridium butulinum in cheese, L. monocytogenes in cheeses such } \\
\text { as Camembert, Ricotta and Manchego }\end{array}$ \\
\hline & Pediocin $\mathrm{AcH}$ & $\begin{array}{l}\text { Effective against milk and Cheddar and Munster cheeses against } L \text {. } \\
\text { monocytogenes, } S \text {. aureus and E. coli O157:H7 lacticin against } \\
\text { undesirable LAB. L. monocytogenes and B. cereus in Cheddar, } \\
\text { Cottage cheese and yogurt and enterocin AS- } 48 \text { against } B \text {. cereus, } S \text {. } \\
\text { aureus and L. monocytogenes in milk and Manchego cheese. }\end{array}$ \\
\hline \multirow[t]{3}{*}{ 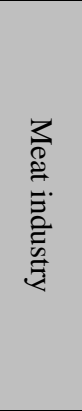 } & $\begin{array}{l}\text { Nisin, Enterocin AS- } 48 \text {, Enterocins A } \\
\text { and B, Sakacin, Leucocin A and } \\
\text { especially Pediocin PA-1/AcH alone or } \\
\text { in combination with several } \\
\text { physicochemical treatments like } \\
\text { modified atmosphere packaging, high } \\
\text { hydrostatic pressure (HHP), heat and } \\
\text { chemical preservatives }\end{array}$ & Quite effective against $L$. monocytogenes and other pathogens. \\
\hline & Bacteriocinogenic LAB & Bio-protective cultures to protect pathogens in food processing. \\
\hline & Pediocin PA-1/AcH & $\begin{array}{l}\text { It is more suitable for use in meat and meat products than nisin but } \\
P \text {. acidilactici is not an indigenous meat strain. }\end{array}$ \\
\hline \multirow{3}{*}{ 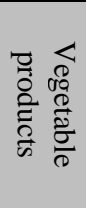 } & Nisin & In tinned vegetables and fruit juices. \\
\hline & Pediocin PA-1/AcH & In salad and fruit juices. \\
\hline & Enterocin AS-48 & $\begin{array}{l}\text { Effective against } B \text {. cereus in rice and vegetables and against } \\
\text { pathogens such as } E \text {. coli } \mathrm{O} 157: \mathrm{H} 7, \text { S. aureus and the spoilage } \\
\text { bacterium Alicyclobacillus acidoterrestris. }\end{array}$ \\
\hline \multirow{2}{*}{ 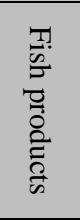 } & Combination of nisin and Microgard & $\begin{array}{l}\text { Gram-negative microorganisms generally encountered in fresh } \\
\text { chilled salmon and L. monocytogenes in frozen thawed salmon. }\end{array}$ \\
\hline & $\begin{array}{l}\text { Bacteriocins culture containing } \\
\text { Carnobacterium divergens culture in } \\
\text { combination with lactic acid, sodium } \\
\text { chloride, and/or nisin }\end{array}$ & In inhibition of L. monocytogenes in rainbow trout. \\
\hline
\end{tabular}

Some of the commercially available phage preparations have got approval from FDA like Listex and LMP 102 for ready-to-eat meat, anti-E. coli and anti-Salmonella phage-based product to treat live animals prior to slaughtering.

It also helps in detection of food borne pathogens in which phage specificity and the efficacy of host recognition is generally exploited.

\section{Endolysins}

Endolysins are also called phage lysins which are phage-encoded peptidoglycan hydrolases employed by the majority of bacteriophages to enzymatically degrade the peptidoglycan layer of the host bacterium. Bacteriophages are utilizing the endolysins at the end of their replication cycle to degrade the peptidoglycan of the bacterial host.

Endolysins are good antimicrobials because of absence of an outer membrane in the Gram-positive bacterial cell wall and its easy accessibility to peptidoglycan (Young et al., 2005). Structurally most of the endolysins lack secretory signals and their access to peptidoglycan inside the cell is dependent on small hydrophobic proteins, named holins. Endolysins are mostly having narrow spectrum lytic activity and often restricted to phage host bacterial activity from which they are originally derived. However, some exceptions are also existed like Enterococcal phage lysin whch are capable to lyse enterococci as well as Streptococcus pyogenes, group B streptococci and S. aureus (Yoong et al., 2004).

\section{Role of Endolysins in food system}

The role of endolysins in food bio-preservation is still in infancy. But there are number of endolysins are isolated to work against several zoonotic and foodborne pathogens. The good thing in this regard is the non-existence of resistance against endolysins till date. It is suggested by several scientists now that transgenic cows expressing endolysins have less chances of mastitis and $S$. aureus milk contamination (Donovan et al., 2006). Similarly Staphylococcal endolysin is found capable to reduce $S$. aureus biofilms (Sass and Bierbaum, 2007). Endolysins are also having suggested roles in dairy processing particularly purified endolysins are found to destroy S. aureus in pasteurized milk.

Reports suggested that recombinant LAB are capable to release active Listeria endolysin but their antagonistic activity in milk still requires authentication (Turner et $a l ., 2007)$. It has also been indicated in food safety and has specificity against CBDs. 


\section{Bio-preservation in Indian context}

In India use of fermented food and beverage with local food and crops as well as other biological resources is very common. Fermentation has been used since time immemorial in Indian subcontinent as the means of an effective and low cost means to preserve the food for quality and safety. The typical examples are idli, dosa, dhokla, khaman in south India, kinema in Eastern Himalayan region, jalebi in north India, sez in Uttaranchal. Fermented milk product like dahi is popular in almost whole India. Fermented fish products like Ngari and Hentak are famous in Manipur, tungtap in Meghalaya. Dahi is a very popular product produced by fermentation in India. During conversion of milk to dahi by culture bacteria several types of organic acids like lactic acid, acetic acids are produced. In addition, metabolites like lactocidin, nicin and acidophilin are also produced and exhibited antibacterial property. Though, the use of microbes in fermentation is unknowingly. So the scientific knowledge and validation need to be done to popularize the biopreservation facts with traditional knowledge.

\section{Conclusion}

Overall bio-preservation of food by bacteriocins, bacteriophages and endolysins has promising role in food processing, preservation and food safety. Bacteriocins and endolysins are believes to have more suitability for DNA shuffling and protein engineering to generate highly potent variants with expanded activity spectrum. Genetically modified bacteriophages may also be helpful in bio-preservation but their safety issues must be addressed properly before selection as bio-preservative agent. The bacteriocins may be a good hurdle agent and successfully can be incorporated into packaging films and combined with modified atmosphere packaging (MAP). Similarly phages and endolysins have been successfully combined with nisin and high hydrostatic pressure enhances endolysin activity Bacteriophages and endolysins has also been advocated as good disinfectants in food environments, including food handlers, but delivery strategies have to be implemented. So to attain bio-preservation in most holistic manner it is mandatory to prove the freeness from resistance particularly of bacteriocins and bacteriophages. However, endolysisn has no such problem indicated till date. But phages mutate at frequencies significantly higher than that of bacteria. But new phage selection might easily overcome bacterial resistance. Lysogeny process is quite deteriorative because of it bacterial resistant becomes superinfection. Thus temperate phages should always be avoided. But on revolution in genetic technology and advancement in molecular techniques it is expected that bacteriocins, bacteriophages and endolysins will prove the future bio-preservative.

\section{Conflict of interest}

The authors declare that there is no conflict of interests.

\section{References}

Ackermann, H.W. 2007. 5500 Phages examined in the electron microscope. Arch. Virol. 152, 227-243.

Atterbury, R.J., Dillon, E., Swif,t C., Connerton, P.L., Frost, J.A., Dodd, C.E., Rees, C.E. and Connerton, I.F. 2005. Correlation of Campylobacter bacteriophage with reduced presence of hosts in broiler chicken ceca. Appl. Environ. Microbiol. 71, 4885-4887.

Azeredo, J. and Sutherland, I. 2008. The use of phages for the removal of infectious biofilms. Curr. Opin. Biotechnol. 9, 261-266.

Brede, D.A., Lothe, S., Salehian, Z., Faye, T. and Nes, I.F. 2007. Identification of the propionicin F bacteriocin immunity gene (pcfI) and development of a food-grade cloning system for Propionibacterium freudenreichii. Appl. Environ. Microbiol. 73, 7542-7547.

Breukink, E., Wiedemann, I., Van Kraaij, C., Kuipers, O.P., Sahl, H.G. and De Kruijff, B. 1999. Use of the cell wall precursor lipid II by a pore-forming peptide antibiotic. Sci. 286, 2361-2364.

Brüssow, H. and Kutter, E. 2005. Phage ecology. In E. Kutter \& A. Sulakvelidze, Bacteriophages: biology and applications. Florida: Boca Raton CRC Press. pp: $129-163$.

Carlton, R.M., Noordman, W.H., Biswas, B., De Meester, E.D. and Loessner, M.J. 2005. Bacteriophage for control of Listeria monocytogenes in foods: Genome sequence, bioinformatic analyses, oral toxicity study, and application. Regul. Toxicol. Pharmacol. 43, 301312.

Chopra, L., Singh, G., Jena, K.K. and Sahoo, D.K. 2015. Sonorensin: a new bacteriocin with potential of an anti-biofilm agent and a food biopreservative. Sci. Rep. 5, 13412. doi: 10.1038/srep13412.

Devlieghere, F., Vermeiren, L. and Debevere, J. 2004. New preservation technologies: Possibilities and limitations. Int. Dairy J. 14, 273-285.

Donovan, D.M., Lardeo, M. and Foster-Frey, J. 2006. Lysis of staphylococcal mastitis pathogens by bacteriophage phi11 endolysin. FEMS Microbiol. Lett. 265, 133-489.

Elsabee, M.Z. and Abdou, E.S. 2013. Chitosan based edible films and coatings: a review. Mater. Sci. Eng. C. Mater. Biol. Appl. 33, 1819-1841.

Fiorentin, L., Vieira, N.D. and Barioni. W.Jr. 2005. Oral treatment with bacteriophages reduces the concentration of Salmonella enteritidis PT4 in caecal contents of broilers. Avian Pathol. 34, 258263. 
Ganguly, S. 2013. Basic principles for effective food preservation: a review. Int. J. Pure App. Biosci. $1(6), 84-85$.

García-Bayona, L., Guo, S.M. and Laub, T.M. 2017. Contact-dependent killing by Caulobacter crescentus via cell surface-associated, glycine zipper proteins. eLife. 6, e24869. doi: 10.7554/eLife. 24869.

Gyawali, R. and Ibrahim, S.A. 2014. Natural products as antimicrobial agents. Food Control 46, 412-429.

Hanlon, G.W. 2007. Bacteriophages: an appraisal of their role in the treatment of bacterial infections. Int. J. Antimicrob. Agents 30, 118-128.

Kim, K.P., Klumpp, J. and Loessner, M.J. 2007. Enterobacter sakazakii bacteriophages can prevent bacterial growth in reconstituted infant formula. Int. J. Food Microbiol. 115, 195-203.

Lönnerdal, B. 2011. Biological effects of novel bovine milk fractions. Nestle Nutr Workshop Ser Paediatr Program 67, 41-54.

Lucera, A., Costa, C., Conte, A. and Del Nobile, M.A. 2012. Food applications of natural antimicrobial compounds. Front Microbiol. 3, 287. doi: 10.3389/fmicb.2012.00287.

Martínez, B., Böttiger, T., Schneider, T., Rodríguez, A., Sahl, H.G. and Wiedemann, I. 2008. Specific interaction of the unmodified bacteriocin Lactococcin 972 with the 562 cell wall precursor lipid II. Appl. Environ. Microbiol. 74, 4666-4670.

Modi, R., Hirvi, Y., Hill, A. and Griffiths, M.W. 2001. Effect of phage on survival of Salmonella enteritidis during manufacture and storage of Cheddar cheese made from raw and pasteurized milk. J. Food Protect. 64, 927-933.

Mokoena, M.P. 2017. Lactic Acid Bacteria and Their Bacteriocins: Classification, Biosynthesis and Applications against Uropathogens: A MiniReview. Molecules 22, 1255. doi: 10.3390/molecules22081255.

Raya, R.R., Varey, P., Oot, R.A., Dyen, M.R., Callaway, T.R., Edrington, T.S., Kutter, E.M. and Brabban, A.D. 2006. Isolation and characterization of a new T-even bacteriophage, CEV1, and determination of its potential to reduce Escherichia coli $\mathrm{O} 157: \mathrm{H} 7$ levels in sheep. Appl. Environ.
Microbiol. 72, 6405-6410.

Rilla, N., Martínez, B., Delgado, T. and Rodríguez, A. 2003. Inhibition of Clostridium tyrobutyricum in Vidiago cheese by Lactococcus lactis ssp. lactis IPLA 729, a nisin Z producer. Int. J. Food Microbiol. 85, 23-33.

Rilla, N., Martínez, B. and Rodríguez, A. 2004. Inhibition of a methicillin-resistant Staphylococcus aureus strain in Afuega'l Pitu cheese by the nisin Zproducing strain Lactococcus lactis subsp. lactis IPLA 729. J. Food Protect. 67, 928-933.

Ryan, M.P., Ross, R.P. and Hill, C. 2001. Strategy for manipulation of cheese flora using combinations of lacticin 3147-producing and -resistant cultures. Appl. Environ. Microbiol. 67, 2699-2704.

Salem, A.M. 2012. Bio-preservation challenge for shelf-life and safety improvement of minced beef. Global J. Biotech. Biochem. 7(2), 50-60.

Sulakvelidze, A. and Kutter, E. 2005. Bacteriophage therapy in humans. In: E. Kutter \& A. Sulakvelidze, Bacteriophages: Biology and Applications. Florida: Boca Raton, CRC Press. pp: 381-436.

Turner, M.S., Waldherr, F., Loessner, M.J. and Giffard, P.M. 2007. Antimicrobial activity of lysostaphin and a Listeria monocytogenes bacteriophage endolysin produced and secreted by lactic acid bacteria. Syst. Appl. Microbiol. 30, 58-67.

Wiedemann, I., Breukink, E., Van Kraaij, C., Kuipers, O.P., Bierbaum, G., De Kruijff, B. and Sahl, H.G. 2001. Specific binding of nisin to the peptidoglycan precursor 616 lipid II combines pore formation and inhibition of cell wall biosynthesis for potent 617 antibiotic activity. J. Bio. Chem. 276, 1772-1779.

Xie, L. and van der Donk, W.A. 2004. Posttranslational modifications during lantibiotic biosynthesis. Curr. Opin. Chem. Biol. 8(5), 498507.

Yoong, P., Schuch, R., Nelson, D. and Fischetti, V.A. 2004. Identification of a broadly active phage lytic enzyme with lethal activity against antibiotic resistant Enterococcus faecalis and Enterococcus faecium. J. Bacteriol. 186, 4808-4812.

Young, R.Y., Wang, I.N. and Roof, W.D. 2000. Phages will out: strategies of host cell lysis. Trends Microbiol. 8, 120-128. 